\title{
THE EVENING-PRIMROSES OF SASKATCHEWAN
}

\section{DIANA BIZECKI ROBSON, 811 Avenue E North, Saskatoon, SK S7L 1S7}

\section{Introduction}

This article describes some of the general characteristics of the Eveningprimroses (genus Oenothera) and presents a taxonomic treatment of the genus consisting of a dichotomous key, descriptions and habitat information.

The common name eveningprimrose refers to both the family Onagraceae and the genus Oenothera. In this article it will refer to the latter. The evening-primroses are closely related to the Willow-herbs (Epilobium species), Butterfly-weeds (Gaura species) and Enchanter's Nightshades (Circaea species). Evening-primroses are widespread throughout the world. In Saskatchewan, there are seven species in

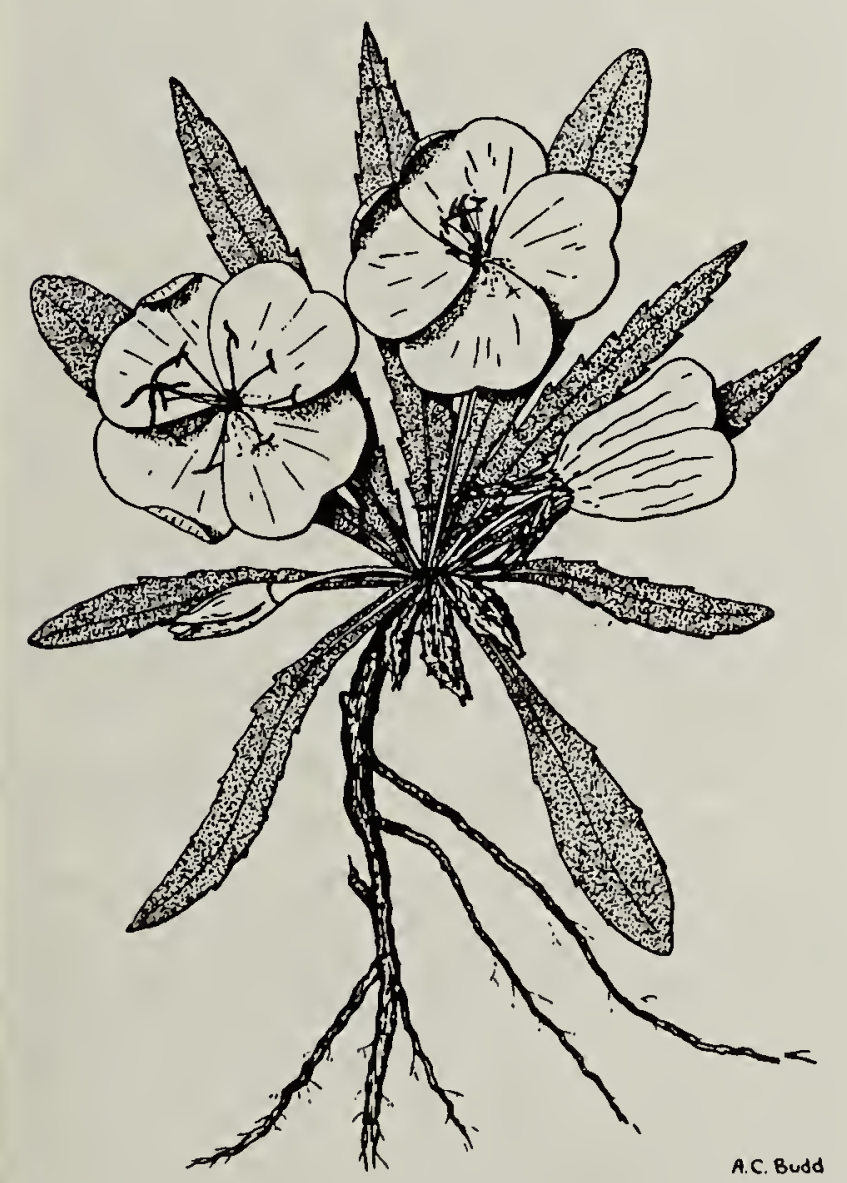

Figure 1. Rock Rose (Oenothera caespitosa). total. The common name tends to cause some confusion. One would think that the evening-primroses are primroses which bloom in the evening. ${ }^{11}$ In fact, they are unrelated to the primroses (Primula species), and while some species do bloom in the early evening, others bloom in the morning. ${ }^{11}$ Those species which flower in the evening are pollinated by nocturnal insects like moths. ${ }^{6}$ In some species, the flowers will bloom in one colour and then fade to a different colour as the day wears on. For example, Rock Rose (Oenothera caespitosa) (Figure 1) and White Evening-primrose $(O$. nuttallii) (Figure 2) have white flowers that turn pink later in the day. ${ }^{7}$ Yellow Lauvauxia (O. flava) blooms yellow and then turns pink. ${ }^{7}$

Evening-primroses occur on dry, eroded areas and around slough margins. Yellow Evening-primrose (O. biennis) (Figure 3 ) and White Evening-primrose are the most common species due to their "weedy" nature; they are found at the edges of fields and roads in sandy soil. Taraxia (O. breviflora) and Yellow Lavauxia occur on heavy clay soils near sloughs. Rock Rose prefers eroded, clay soils whereas Upland Evening-primrose (O. andina) prefers eroded, sandy soils.

Two of our native evening-primroses are considered to be rare in Canada: Upland Evening-primrose (Figure 4) and Taraxia (Figure 5). ${ }^{1}$ These two species are often placed in another genus: Camissonia. Two other species of evening-primrose, Rock Rose (Figure 6) and Yellow 


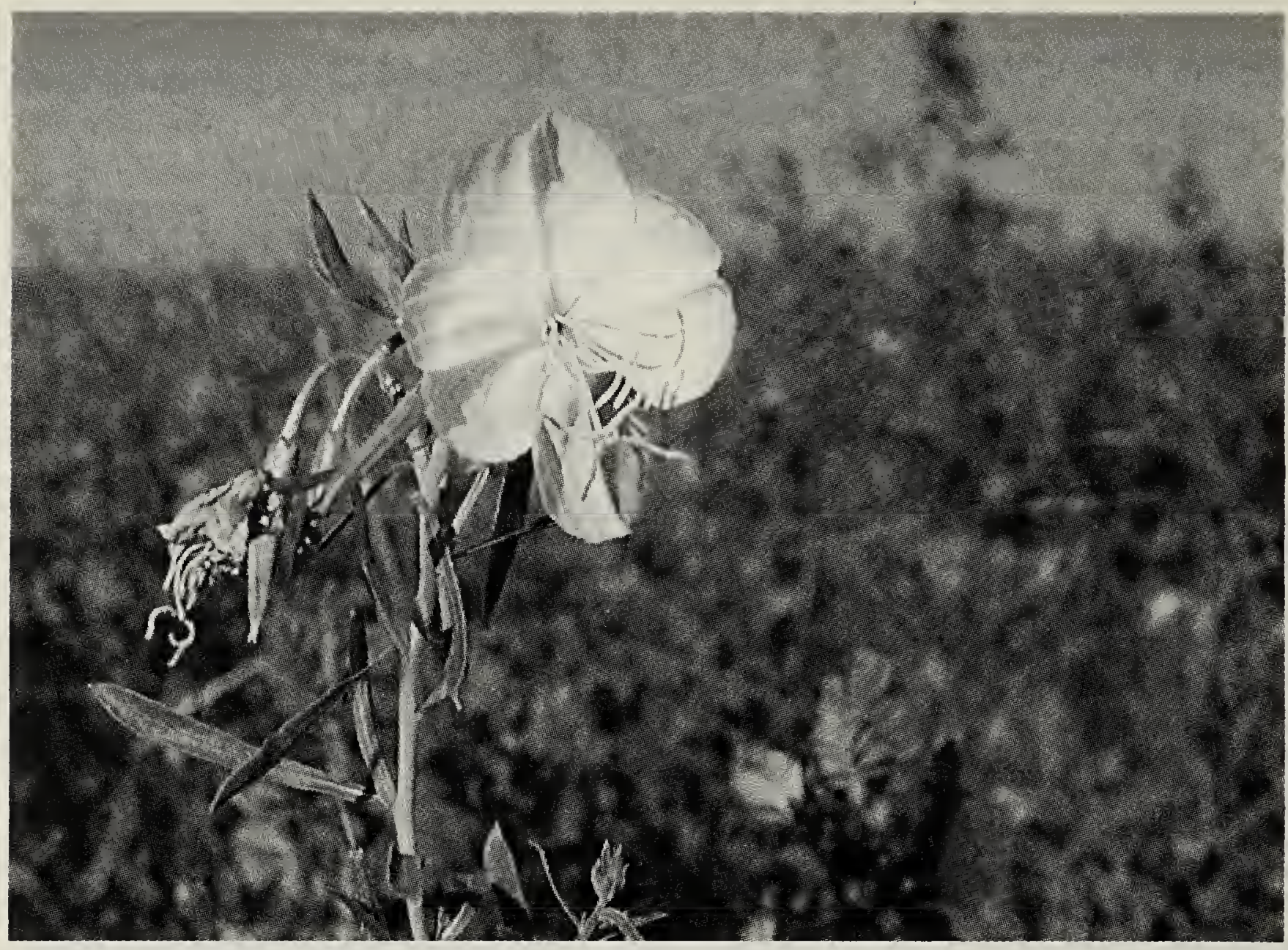

Figure 2. White Evening-primrose (Oenothera nuttallii).

Lavauxia (Figure 7), were considered rare in the past but are now considered only uncommon. ${ }^{5}$

The evening-primroses have several

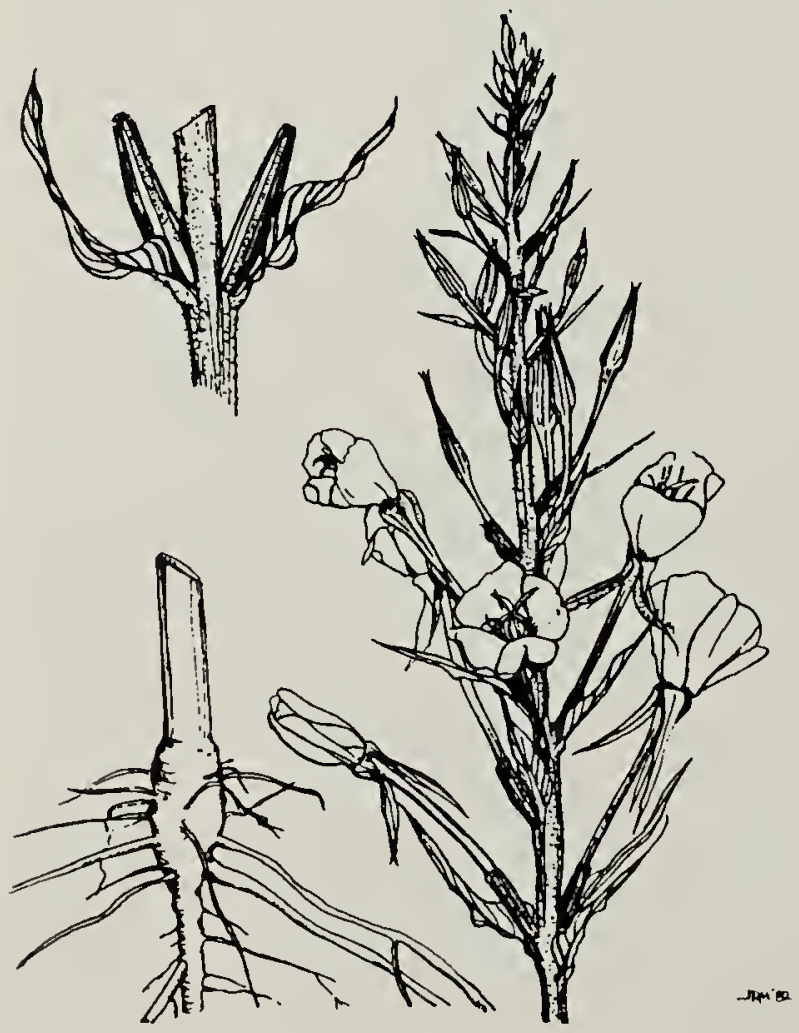

Figure 3. Inflorescence, capsules and rootstock of Yellow Evening-primrose (Oenothera biennis). ${ }^{2}$ important uses. Evening-primrose oil is a source of gamma linolenic acid and is available at many health food stores. ${ }^{3}$ Research suggests that the oil may be useful in treating eczema, asthma, migraines, inflammations, diabetes and arthritis. ${ }^{6}$ The oil may also act as an anti-clotting device. ${ }^{6}$ Native Americans made a tea from Yellow Evening-primrose roots to treat obesity and bowel pains. ${ }^{6}$ The young shoots of Yellow Eveningprimrose can be put in salads and the roots can be boiled and consumed. ${ }^{6}$ Many members of this genus are attractive from a horticultural perspective. Unfortunately, germination studies have only been done for Yellow Evening-primrose and Rock Rose. Yellow Evening-primrose has been successfully cultivated as the seeds have a high germination rate when stratified. ${ }^{2}$ Rock Roses have beautiful flowers but the seed set and germination are poor. ${ }^{2}$ Regarding tourism, the evening-primroses are attractive to nature lovers 


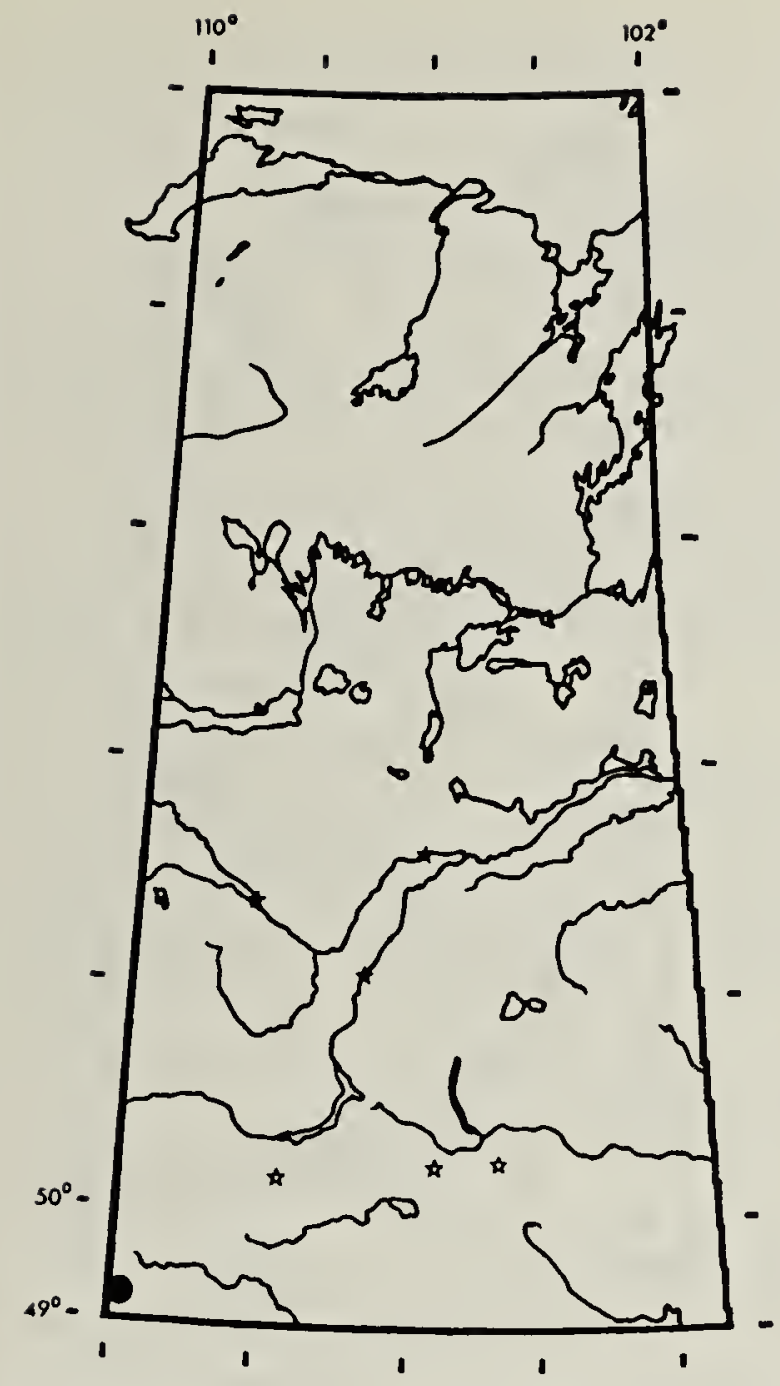

Figure 4. Distribution of Upland Eveningprimrose (Oenothera andina).

because of their large, beautiful, fragrant flowers. Ecologically, eveningprimroses provide nectar for many species of insects and colonize eroded areas preventing soil erosion.

The evening-primroses are easy to identify with their four distinctive, heart-shaped petals, four-lobed stigmas and eight stamens with the anthers attached to the filaments near the middle (Figure 8). The leaves and either the flowers or fruits are sufficient for identification of the species.

\section{Description of Oenothera ${ }^{4,7,8,10}$}

This genus contains annual, biennial and perennial species. Some species lack stems; their leaves and flowers arise directly from the ground. Rarely, the plants are woody at the base. Oenothera species vary in height. The stemless plants are quite short, from $3 \mathrm{~cm}$ to $10 \mathrm{~cm}$,

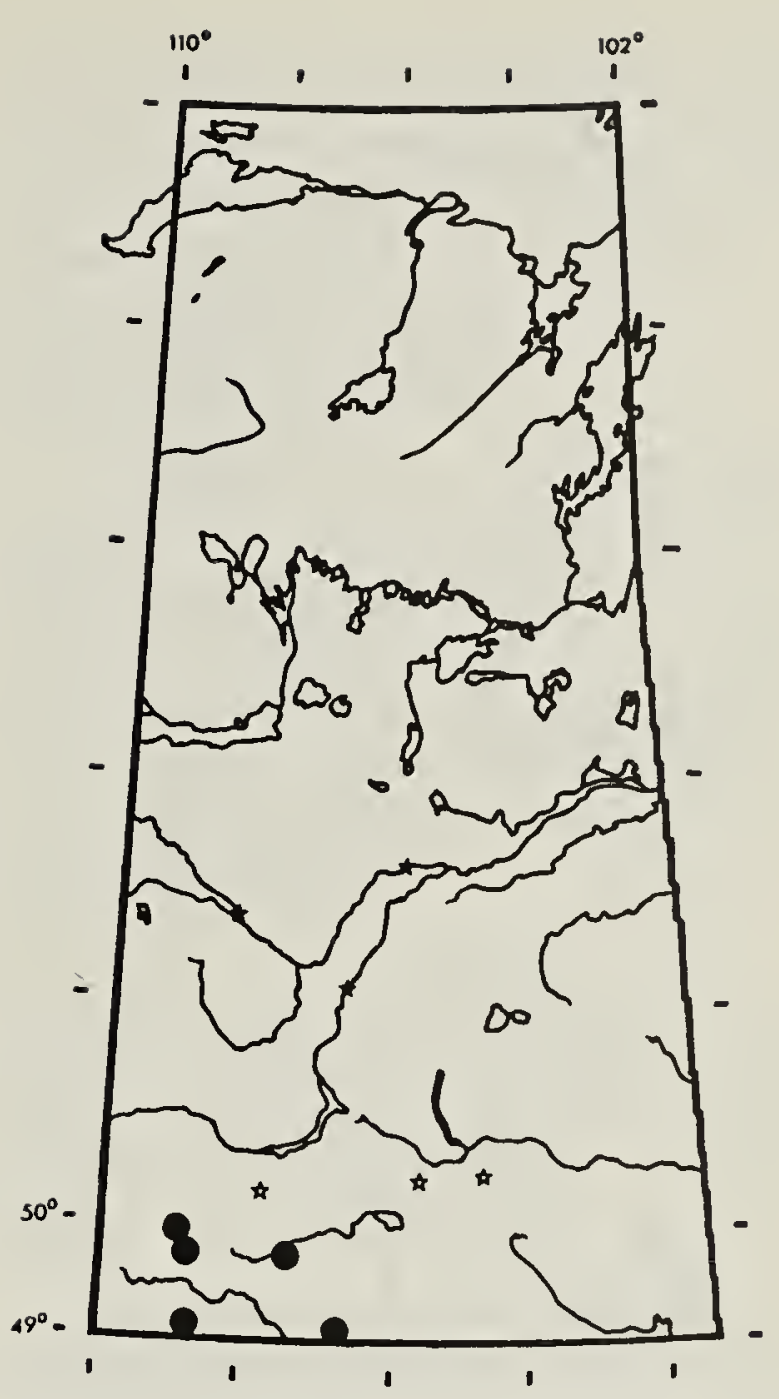

Figure 5. Distribution of Taraxia (Oenothera breviflora).

while those with stems are considerably taller ( $5 \mathrm{dm}$ to $15 \mathrm{dm}$ ). The leaves are alternate on plants with stems and arise from the base of the plant in stemless species.

The flowers are yellow, white or pink and often change colour with age. They are usually large and conspicuous but wither soon after flowering. There are four sepals and four petals. These floral parts are partly fused at the base to form a cup-like structure called a hypanthium (Figure 8 ). The hypanthium is fused to the ovary of the plant.

One of the most distinctive features is the four-lobed stigma especially noticeable when deeply lobed, forming a cross. The ovary occurs below the point of attachment of the sepals, petals and stamens, a position that is referred to as "inferior." The ovary has four chambers that 


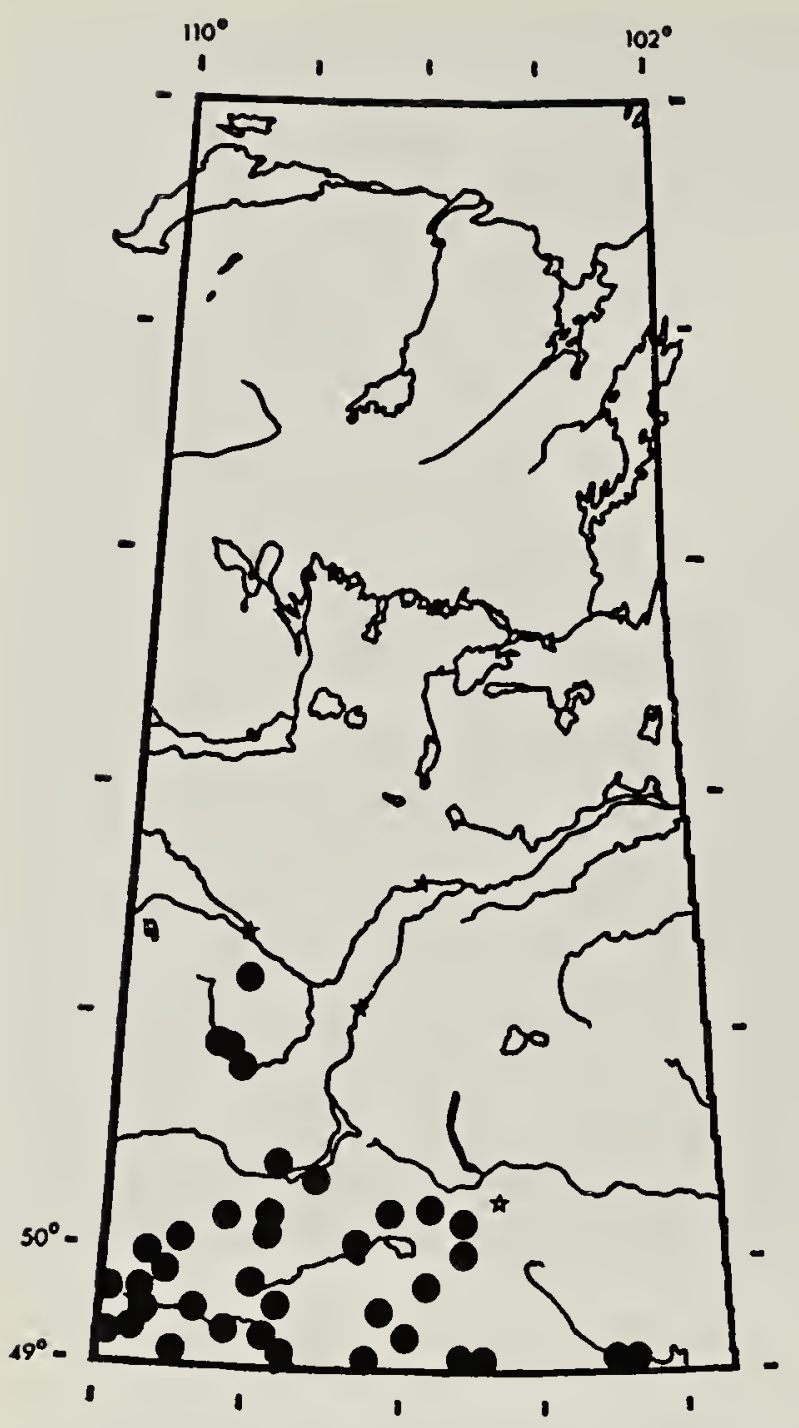

Figure 6. Distribution of Rock Rose (Oenothera caespitosa).

can be seen by cutting the ovary crosswise. The ovaries mature into four-chambered capsules that contain numerous smooth seeds.

There are eight stamens in each flower. In some species the stamens

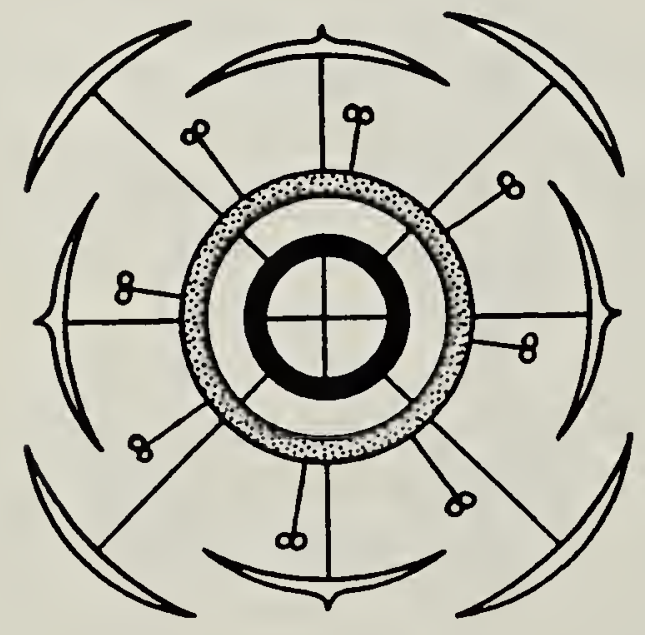

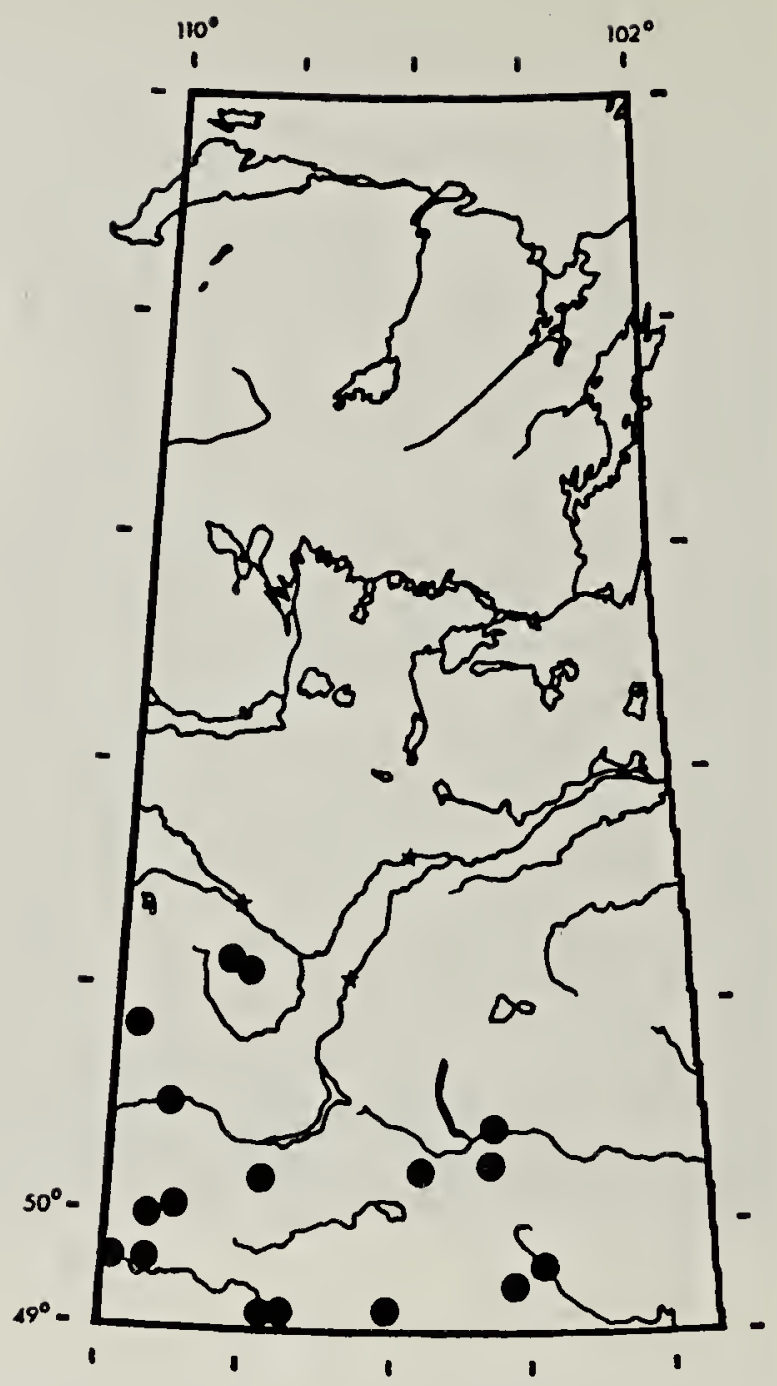

Figure 7. Distribution of Yellow Lavauxia (Oenothera Flava).

are equal in length while in others the stamens opposite the petals (rather than between the petals) are shorter. The anthers of the stamens are attached to the filament at their midpoint, making them rock back and forth like a teeter-totter.

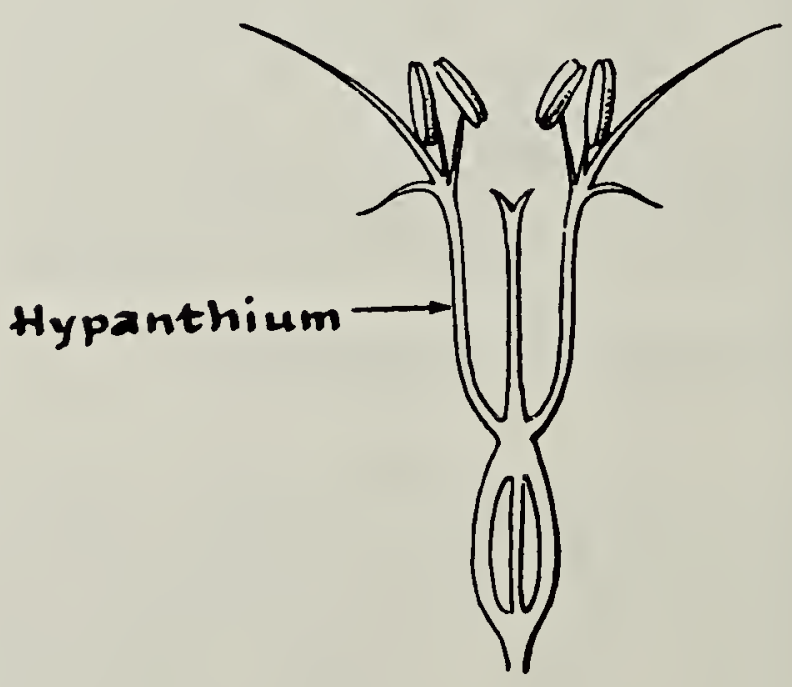

Figure 8. Floral diagrams of Oenothera. 
Identification Key to the

Native Evening-primroses of Saskatchewan ${ }^{4,7,8,10}$

1a. Plants with leafy stems; flowers usually several in leafy spikes (flowers attached directly to the main stem) or racemes (flowers attached to the main stem by short stalks) - 2

1b. Plants without leafy stems; flowers single on stalks arising from the base of the plant; leaves arising from the base of the plant - 5

2a. Plants shrubby, usually with several slender brown, woody stems; stigma not deeply divided into four lobes; flowers yellow with a trumpetshaped base - $O$. serrulata

$2 b$. Plants not shrubby; stems not brown and woody; stigma deeply divided into four lobes - 3

3a. Annual; stems 3-10 cm tall, slender, branched; flowers small, $1-3 \mathrm{~mm}$ long - O. andina

3b. Biennial or perennial; stems taller, stout; flowers larger, more than $5 \mathrm{~mm}$ long - 4

4a. Biennial; flowers yellow, buds erect; stem green or reddish, not much branched; seeds in two rows; leaves oblong to lance-shaped - $O$. biennis

4b. Perennial; flowers white or pinkish, buds nodding; stems white with shreddy bark, usually much branched; seeds in one row; leaves linear to lance-shaped - O. nuttallii

5a. Stigma with four linear lobes; petals greater than $1 \mathrm{~cm}-6$

5b. Stigma rounded, very slightly lobed; petals less than $1 \mathrm{~cm}$, yellow; leaves divided into wavy lobes - $O$. breviflora

6a. Petals greater than $25 \mathrm{~mm}$ long, white aging to pink; capsule not winged, to $4 \mathrm{~cm}$ long; leaves to 2.5 $\mathrm{cm}$ broad, leaf margins are straight or with teeth - O. caespitosa

$6 b$. Petals less than $25 \mathrm{~mm}$ long, yel- low aging to pink; capsule with wings at the margin, to $2 \mathrm{~cm}$ long; leaves to $1.5 \mathrm{~cm}$ broad, deeply divided on the lower third, the terminal portion entire or with wavy lobes - O. flava

\section{Descriptions of Native \\ Evening-primroses ${ }^{4,7,8,10}$}

The plants are arranged alphabetically according to the scientific name as many of the plants have more than one common name. After each scientific name there is a list of the synonyms for that species. A synonym is another scientific name that is used.

1. Upland Evening-primrose or Andean Sundrops/Oenothera andina Nutt. [Camissonia andina (Nutt.) Raven; Sphaerostigma andinum (Nutt.) Walp.]

This species is an annual plant with slender stems that branch from the base. The stems are covered with fine hairs. The plant ranges from 3 to $10 \mathrm{~cm}$ in height. The leaves are alternate, smooth margined and linear or narrowly oblanceolate (lanceshaped with the broadest part at the tip of the leaf). The leaves are 1 to 3 $\mathrm{cm}$ long. The flowers are yellow and clustered in the axils of the leaves. The petals are 1 to $1.5 \mathrm{~mm}$ long. The stigma is rounded. Capsules are 5 to $6 \mathrm{~mm}$ long, spindle-shaped, greyish and with four angles. This plant is rare and occurs on dry sandy slopes in the western Prairies.

2. Yellow or Common Eveningprimrose/Oenothera biennis L.

This species is a biennial plant with a stout taproot. It forms a leafy rosette in the first year and an erect, stiff stem in the second year when it grows to 5-15 dm tall and usually has branches. The stems are greyish or reddish in colour and are covered with small hairs. The leaves are ascending or spreading and are attached directly to the stem. Leaves 
are lance-shaped or somewhat oval, densely or sparsely hairy and sometimes with small teeth on the edges. The leaves vary in length from 2 to $14 \mathrm{~cm}$. The flowers are in leafy, terminal spikes. The large, yellow flowers are erect and open in the evening. The hypanthium tube is about $3 \mathrm{~cm}$ long. The sepals are united at first except for very short free tips and later separate and bend back. The petals are 12 to $25 \mathrm{~mm}$ long. The stigma is deeply divided into four lobes. Capsules are 2 to 3 $\mathrm{cm}$ long, erect and with small hairs. The plants are in bloom from July to October. This species is very common on lighter soils throughout the southwestern portion of the Prairies and occasionally in the boreal forest.

\section{Taraxia/Oenothera breviflora T. \& G. [Camissonia breviflora (T. \& G.) Raven; Taraxia breviflora (T. \& G.) Nutt.]}

Taraxia is a stemless, perennial species with a rosette of leaves close to the ground. The leaves are 5 to $12 \mathrm{~cm}$ long, deeply divided and covered with fine hairs. The petals are 5 to $8 \mathrm{~mm}$ long. When the petals first open they are yellow; as they dry out they turn red. The stigma is knobbed. The capsules are about $1.5 \mathrm{~cm}$ long, narrowly oval and covered with hairs. This species is very rare and is found on heavy clay soils of slough margins in the western Prairies.

4. Rock Rose, Butte Primrose, Gumbo or Tufted Evening-primrose/ Oenothera caespitosa Nutt. [Pachylophus caespitosus (Nutt.) Raim.]

This species is a perennial with a thick, woody root. The plants are stemless or nearly so. The leaves are lance-shaped to oblanceolate, sometimes with small hairs on the margins. The leaves are 1-2 dm in length and are sometimes toothed or wavy on the margins. The leaf stalks are winged. The flowers are sessile in the crown of the plant and have a sweet scent. The hypanthium tube is 3 to $10 \mathrm{~cm}$ long. The petals are 2 to $4 \mathrm{~cm}$ long. When the petals open in the morning they are white, but they fade to pink later in the day. The stigma is deeply divided into four linear lobes. The capsules are about $2.5 \mathrm{~cm}$ long, woody and four-angled; the angles having wavy crests on them. Sometimes the capsules have small bumps on them called tubercles. Rock Rose blooms from May to August. It is not common and is found on dry hillsides of gumbo or clay soil and sometimes on gumbo flats throughout the Prairies.

5. Yellow Lavauxia/Oenothera flava (A. Nels.) Garrett [Lavauxia flava A. Nels.]

Yellow Lavauxia is a stemless perennial with a fleshy taproot and rosette of leaves near the ground. The leaves are 1 to $2 \mathrm{dm}$ long, oblanceolate in shape, deeply divided and coarsely toothed. The midrib of the leaves on the underside is very prominent. The leaves are sometimes hairy on the margin. The hypanthium tube is 4 to $7 \mathrm{~cm}$ long. The petals are 12 to $18 \mathrm{~mm}$ long. When they first bloom they are yellow; later in the day they turn pink. The stigma has four linear lobes. The capsules are 2 to $3 \mathrm{~cm}$ long, four-angled, with winged edges. The plants are in bloom from May to August. This species is not very common and can be found in valleys, slough margins, clay flats and drainage channels in the western Prairies.

6. White Evening-primrose/Oenothera nuttallii Sweet [Anogra nuttallii (Sweet) A. Nels.]

This species is a perennial with a white fleshy rootstock. The erect stems are white, somewhat shiny 
and have shreddy bark. The stems are often branched. The plant ranges in height from 4 to $10 \mathrm{dm}$. The leaves are 5 to $10 \mathrm{~cm}$ long. The leaves are linear to linear-oblong and taper at the base. The upper leaf surface has no hairs but there are hairs beneath the leaves. The flowers have an unpleasant scent. The drooping flowers grow out of the leaf axils. The hypanthium tube is 2 to $2.5 \mathrm{~cm}$ long. The petals are about $2 \mathrm{~cm}$ long. Like the Rock Rose, the petals of this species are white when they open and pink at the end of the day. The stigma is deeply divided into four lobes. The capsules are 2 to $3 \mathrm{~cm}$ long, slender, somewhat curved and four-angled. They are in flower from June to September. This species is very common and is found on roadsides in light or sandy soils in the Prairies and parkland. It is persistent on cultivated fields.

7. Shrubby Evening-primrose / Oenothera serrulata Nutt. [Calylophus serrulatus (Nutt.) Raven; Meriolix serrulata (Nutt.) Walp.]

This perennial species has a woody base. The plants range in height from 1 to $5 \mathrm{dm}$. The stems are slender, brown and erect or decumbent. The leafy branches are more or less hairy. The leaves are $2-5 \mathrm{~cm}$ long, alternate, spatula shaped, linear or linear oblong. The leaf margins are finely toothed or toothless, and often with short, stiff hairs. The flowers grow out of the axils of the upper leaves. The hypanthium is trumpet-shaped and four-angled. The sepals have a ridge down the back. The petals are yellow and wavy on the margins. The stigma is disc-shaped and shallowly fourlobed. The capsule is slender, greyish and 15 to $25 \mathrm{~mm}$ long. This spe- cies is not common and can be found on dry, sandy prairie and hillsides in the Prairies and parkland.

\section{Literature Cited}

1. ARGUS, G.W. and K.M. PRYER. 1990. Rare vascular plants in Canada. Canadian Museum of Nature, Ottawa.

2. CURRAH, R., A. SMRECIU and $M$. VAN DYK. 1983. Prairie wildflowers. Friends of the Devonian Botanic Garden, University of Alberta, Edmonton.

3. FOSTER, S. and J.A. DUKE. 1990. Eastern/Central medicinal plants. Houghton Miffin Co., Boston.

4. GREAT PLAINS FLORA ASSOCIATION. 1986. Flora of the Great Plains. University Press of Kansas, Lawrence, Kansas.

5. HARMS, V.L., P.A. RYAN and J.A. HARALDSON. 1992. The rare and endangered vascular plants of Saskatchewan. The W.P. Fraser Herbarium, University of Saskatchewan, Saskatoon.

6. JOHNSON, D., L. KERSHAW, A. MACKINNON and J. POJAR. 1995. Plants of the western boreal forest and aspen parkland. Lone Pine Publishing, Edmonton, Alberta.

7. LOOMAN, J. and K.F. BEST. 1979. Budd's flora of the Canadian prairie provinces. Canadian Government Publishing Center, Supply and Services Canada, Hull, Quebec.

8. MOSS, E.H. 1983. Flora of Alberta. University of Toronto Press, Toronto.

9. PORTER, C.L. 1959. Taxonomy of flowering plants. W.H. Freeman and Company, San Francisco.

10. SCOGGAN, H.J. 1979. The flora of Canada. National Museum of Natural Sciences, National Museums of Canada, Ottawa.

11. WERNERT, S.J. 1982. North American wildlife. Reader's Digest Association, Inc., Pleasantville, NY. 